\title{
MENULIS, KOMUNIKASI DAN HUMANIORA
}

\author{
Dominikus Tulasi \\ Jurusan Marketing Communication, Fakultas Komunikasi dan Multimedia, \\ Bina Nusantara University, Jln. K.H. Syahdan No. 9, Palmerah, Jakarta Barat 11480
}

\begin{abstract}
This article is a potrait of constructing frame of mind in writing, communication and human being. Communication is a process of transforming idea to the other in which the idea can be formed through encoding process to be reformed and reconstructed in decoding process by receiver. The new order framework is the new paradigm of mind. Further more, writing is an action to pour idea to be sedimented and embeded in the form of documented written. Related to writing, communication means transfering message from sender to the other either verbal and or non-verbal process. On the other hand, humaniora is a realm of meaning within human spirit to be humanized and civilized by oneself through education. Educating human being is also a teaching and learning process toward oneself-personalization. The personalization is so called humanization process.
\end{abstract}

Keywords: communication, humaniora, writing, education

\begin{abstract}
ABSTRAK
Artikel ini merupakan sebuah potret dari kerangka pikiran dari penulisan, komunikasi, dan makhluk hidup. Komunikasi adalah proses perubahan ide menjadi bentuk lain, yang bisa berubah melalui proses enkoding untuk diubah dan direkonstruksi pada proses decoding oleh penerima. Bentuk baru dari rangka kerja adalah pembaharuan paradigm pikiran. Terlebih, menulis adalah aktivitas penuangan ide untuk diendapkan dan ditanamkan pada bentuk dokumentasi tertulis. Sementara itu, komunikasi berarti menyampaikan pesan dari pengirim kepada penerima, baik secara verbal maupun non-verbal. Selain itu, humaniora adalah dunia makna dalam jiwa manusia untuk menjadi manusiawi dan beradab dengan sendirinya melalui pendidikan. Mendidik manusia juga merupakan proses pengajaran dan pembelajaran melalui personalisasi diri. Personalisasi ini disebut juga proses humanisasi.
\end{abstract}

Kata kunci: komunikasi, humaniora, menulis, pendidikan 


\section{PENDAHULUAN}

Merangkai pemahaman untuk membentuk kerangka berpikir (mindframe) merupakan alur logis setiap sarjana. Menulis merupakan bagian dari aktivitas otak untuk merangkai kata dalam kalimat yang tersusun membentuk makna tersimpan dalam tulisan. Sebaliknya, bercerita adalah ungkapan diri untuk meng-komunikasi-kan pikiran bermakna kepada orang lain secara lisan. Menulis juga berarti memadukan jaringan makna (realm of meaning) yang tersimpan dalam otak untuk disedimentasi-kan dalam bentuk tulisan. Mampu menulis belum tentu mampu berbicara. Mampu berbicara juga belum tentu mampu menuangkannya dalam bentuk tulisan.

Berbicara tentang humaniora sangat menarik, oleh karena bidang ini merupakan pengetahuan yang menyentuh dan bersentuhan langsung dengan manusia dan kemanusiaan. Bercerita dan bernarasi tentang manusia tidak akan pernah selesai, karena kehidupan bermuara pada manusia sebagai subyeknya. Hidup manusia senantiasa bergumul tentang dirinya dan dunianya. Dengan kata lain, semua aktivitas dan yang dikerjakan manusia, diperuntukkan bagi manusia. Perkembangan ilmu pengetahuan dan tekonologi canggih, semuanya diperuntukkan bagi hidup manusia itu sendiri.

Historisasi tentang munculnya humanisme bergerak dan dikultivasi secara eksplisit pada era reneissance. Sebelum era ini, semua aspek kehidupan selalu bermuara pada Tuhan. Namun, kenyataan hidup dan perilaku disaat itu tidak membuktikan bahwa mereka lebih baik hidupnya hanya dengan sering menyebut nama Tuhan. Hampir setiap tafsir tentang semua aspek kehidupan selalu dihubungkan dengan nama Tuhan. Namun, setelah munculnya era reneissance, lorong pemahaman yang God minded bergeser secara signifikan menuju kepada manusia dan alam sebagai pusatnya. Pada era inilah berubah mindset dan pemahaman masyarakat dijaman itu bahwa manusia merupakan pusat perjuangan. Masuk surga dan neraka bukan urusan manusia, melainkan mutlak keputusan Tuhan. Manusia hanya berhak untuk memperjuangkan kehidupan yang lebih baik dan maju.

"Ketika aku berpikir, maka aku ada” (cogito ergo sum), inilah pernyataan Rene Descartes yang semakin memperteguh existensi manusia sebagai pusat perjuangan untuk mengeksplorasi potensi diri dan alam pikirnya. Dengan pernyataan Descartes tersebut manusia pantas meneguhkan diri sebagai penemu (inventor) untuk mengubah diri dan alam sekitarnya. Berpikir menggambarkan existensi manusia. Berpikir juga berarti menggerakkan kognisi. Berpikir ibarat manusia berdiri ditengah hutan belantara yang tidak mengetahui arah mata angin utara, selatan, timur serta barat. Dan, untuk mengetahui dimana posisi kita ditengah hutan belantara, hanya ada satu cara yakni bergerak kearah mana saja yang mungkin untuk cepat mendapat haluan memandang keluar. Dengan penemuan Descartes inilah manusia membudayakan alam pikirnya.

Lahirnya humanisme sebagai suatu aliran yang mengajak manusia untuk kembali mendiseminasi-kan kebudayaan Yunani kuno menjadi bukti akan tingginya manusia membudayakan tindakan dan potensi dirinya. Hal ini tidak dimaksudkan untuk mendewakan manusia sebagai tuhantuhan kecil dimuka bumi ini. Namun, harus diakui bahwa kita adalah pusat penciptaan Tuhan, dan diberi akal budi untuk berbudaya dalam segala aspek kehidupan. Kita diharapkan untuk mengungkap semua substansi dan esensi kehidupan demi kebaikan bersama. Diera ini pula, bidang-bidang pengetahuan seperti: filsafat, sejarah dan sastra menjadi sentra perjuangan dalam kehidupan. Lahir istilah seperti, studia humanitatis dan literae humaniora yaitu, bidang kajian tentang manusia dan kebudayaannya. Kebudayaan juga berarti cara khas manusia berada bersama alamnya, dan bagaimana proses menyesuaikan diri dengan lingkungan alamnya untuk memenuhi semua kebutuhan hidupnya. Kebudayaan juga berarti cara hidup untuk kebaikkan bersama. 


\section{PEMBAHASAN}

\section{Menulis Ide Ibarat Berenang}

Suatu ketika penulis bertukar pikiran dengan salah seorang dosen di Perguruan Tinggi lain. Dalam persepsi penulis rekan ini akan berbicara dari pengalaman yang matang tentang menulis. Ternyata baginya menulis adalah suatu proses yang rumit, namun menyenangkan. Rumit karena membutuhkan banyak referensi dan pengalaman menulis. Menyenangkan tatkala kita sudah berada ditengah dan ujung proses. Inilah gejala umum yang terjadi hampir di semua perguruan tinggi di Indonesia.

Penulis berpendapat bahwa menulis adalah suatu hal yang harus dilatih sekaligus disenangi untuk digeluti. Menciptakan situasi yang kondusif bagi diri untuk mulai menulis menjadi suatu keniscayaan. Kebanyakan orang berkata rumit, karena kita selalu tidak mencoba mulai. Rumit karena kita selalu berada diawal proses. Maka benar pameo yang mengatakan, setiap kesuksesan berawal dengan kerumitan.

Menuliskan ide dapat dianalogikan ibarat berenang dikolam. Seorang pemula akan bersusah payah untuk mengangkat kepalanya agar bisa mendapatkan udara saat mengayuh dan menggarukgaruk air, diiringi tendangan kaki untuk beranjak dari tempat semula. Rumit rasanya untuk melayang di atas air kolam. Namun, suatu ketika berkat latihan dan ketekunan kita akan dengan mudah menjelajahi seluruh kolam tanpa kesulitan. Menulis juga dapat dianalogikan seperti orang bersepeda. Awalnya akan kesulitan untuk tenang dan konsentrasi mengayuh sepeda. Bahkan, akan jatuh bangun untuk duduk tenang di atas sepeda. Namun suatu ketika, berkat latihan yang terus-menerus, bersepeda menjadi sesuatu yang gampang dan menyenangkan.

Penulis sengaja mengambil contoh berenang dan bersepeda. Sebab, kedua analogi tersebut sifatnya privat atau pribadi, dan bukan berlatih dalam bentuk tim atau bersama dengan pihak lain seperti latihan sepak bola misalnya. Berenang adalah aktivitas untuk kehebatan ketrampilan diri sendiri. Manfaat derivatifnya sangat beragam untuk kepentingan dan kesehatan tubuh kita. Demikian juga bersepeda, manfaat derivatifnya sangat beragam untuk diri sendiri, namun berdampak tinggi kepada pihak lain yang menirunya. Oleh karena itu, berlatih berenang dan bersepeda, jauh lebih penting daripada berbicara tentang metode berenang dan bersepeda. Apalagi hanya menjadi penonton. Kita tidak akan pernah ditonton karena kita adalah penonton ulung. Maka, lebih baik berlatih untuk ditonton orang lain, daripada berlatih untuk menonton orang berenang dan bersepeda. Proposi-proposi diatas merupakan dalil-dalil umum yang berlaku universal untuk semua bentuk aktivitas manusia. Bahwa semua permulaan adalah kerumitan. Dan kerumitan adalah harga yang harus dibayar pada setiap awal aktivitas.

Menulis juga berarti proses menuangkan ide dan logika untuk dikomunikasikan kepada pihak lain. Menuliskan ide melalui logika juga berarti proses menyihir orang lain untuk ikut dengan kita. Ini adalah suatu cara bagaimana mempengaruhi pikiran orang untuk ikut bersama melanglang dunia kita dan dunia lain. Dunia dimana tak seorangpun mengetahui sebelumnya. Oleh karena kitalah yang menciptakan paradigma dan kerangka berpikir baru (new frame of mind), yang didalamnya memuat dan termuat ide-ide baru.

Jika pembaca pernah menyaksikan acara Uya memang Kuya di SCTV, maka disitu terlihat jelas bahwa apa yang dialami oleh tersihir benar-benar dieksplorasi oleh Uya. Uya adalah dalang yang mampu menyihir tersihir dengan cara mana yang dia kehendaki. Akan tetapi bagi kita yang penting adalah bahwa, dalam acara itu kita juga ikut tersihir bukan hanya isi ungkapan yang disihir, melainkan juga oleh cara menyihirnya. Itulah yang penulis maksudkan dengan dunia lain, dunia baru dimana tak seorangpun mengetahui sebelumnya. 
Ungkapan spontan pengalaman dan isi hati tersihir, ibarat rahasia yang tersimpan didalam dunia tak terjangkau oleh siapapun sebelumnya. Maka menulis juga berarti kemampuan untuk mempengaruhi pikiran orang lain untuk masuk kedalam pikiran kita. Bagi pembaca, akan menyenangkan jika mereka dibawa kedunia kita. Dan bagi penulis, akan menyenangkan karena telah mampu mengajak pihak lain masuk kedalam kerangka berpikirnya.

Oleh karena itu, menulis karena dipaksa akan menghasilkan tulisan yang terpaksa. Hasil tulisan akan sangat terpaksa dibaca, bahkan belum tentu dibaca orang. Sebaliknya, menulis karena hobi dan senang terdorong dari dalam, comes from within akan menghasilkan karya tulis yang menyenangkan untuk dibaca oleh orang lain disekitar kita. Bahkan, tulisan itu akan selalu menarik dan menggoda untuk dibaca.

Dalam kaitan dengan menulis untuk menyihir pembaca, satu hal penting lain menurut penulis adalah keindahan dan kelugasan bahasa, tanpa mengabaikan norma-norma menulis ilmiah. Oleh karena, nilai ilmiah tidak hanya terletak pada penemuan yang bersifat 'ekstraktif' dan tangible atau terlihat, melainkan juga lapisan bawah yang membungkusnya. Ibarat produk bernilai tinggi bukan hanya karena wujud barangnya melainkan juga karena semua lapisan yang melingkupinya termasuk fitur-fitur serta seni membungkusnya. Bahkan, jauh lehih dasyat nilainya adalah kekayaan merek (brand equity) yang tresimpan dan termuat didalamnya. Yang disebutkan terakhir nilainya bersifat tak terlihat (intangible). Dia menyembunyikan diri di dalam yang terlihat. Pantaslah kita katakan: produk fisik yang tersimpan rapih didalam lemari-lemari jualan, akan kedaluwarsah dan punah. Namun, yang tak terlihat dibaliknya bersifat abadi (endless).

Pikiran dan logika manusia adalah misteri yang harus kita eksplorasi dan eksploitasi untuk menemukan esensi dan substansi masalah yang ada disekitar dunia kita. Karena dunia disekitar kita adalah fenomenon-fenomenon yang mengandung rahasia-rahasia kehidupan. Dibalik semua rahasia itu, kita sebut sebagai penemuan. Penemuan yang sebelumnya sudah dihipotesiskan. Maka kerangka logika Hegel untuk merunut fenomena dengan proses: thesis-antitesis-syntesis-menarik untuk dijadikan acuan berpikir kita. Oleh karena, kita sebagai peneliti tidak hanya mengejar kecepatan melainkan juga percepatan. Kita tidak hanya memburu yang kuantitatif-positifistik, melainkan juga yang kualitatif-konstruktif dibaliknya. Kita tidak hanya ingin melihat yang ekstraktif tersimpan, melainkan juga yang substansial termuat. Kepenuhan esensinya akan dapat dirasakan, manakala kita mampu menginternalisasi dua hal sekaligus yakni apriori deduktif dan aposteriori induktif untuk memunculkan sintesa baru. Dalam kerangka inilah abstraksi pikiran manusia menjadi penting atas dasar ini: 'bentuk yang dirubah dan berubah tidak bertambah, yang terlihat bertambah tidak mengurangi'. Alam ini sebenarnya konstan, merubah pasir menjadi gelas adalah transformasi yang mengalami proses perubahan bentuk, namun tidak menambah atau mengurangi sedikitpun materi yang ada di alam ini. Yang kita alami adalah transformasi-transformasi perubahan terus menerus, yang disebabkan oleh hukum alam maupun yang disengaja oleh manusia melalui proses: kognitifafektif-psikomotor. Jadi, yang berubah sebetulnya adalah pikiran manusia untuk merubah yang konstan ada. Maka yang tetap adalah perubahan itu sendiri.

Dalam rangka proses berpikir abstraktif, belajar dan mengajar (teaching and learning) terus digumuli oleh para ahli untuk menemukan solusi bagaimana meningkatkan abstraksi belajar berpikir yang meningkat. Benyamin Bloom tokoh yang berhasil merumuskan tingkatan berpikir dan menjadi acuan dan referensi semua lembaga pendidikan formal patut kita jadikan acuan untuk menyusun kerangka berpikir kita yang bermula dari sekedar mengingat-meningkat menjadi memahamibertambah menjadi menerapkan—memasuki wilayah menganalisis—meningkat lagi menjadi mengevaluasi dan diakhiri dengan mencipta atau membuat sintesis baru. Inilah proses transformasi pikiran untuk merubah segala fenomena yang ada disekitar kita. Maka tidak mengherankan bahwa Bloom lebih fokus membahas untuk mendalami bagian kognitif manusia. Sedangkan aspek afektif dan psikomotor adalah dua aspek lain yang sifatnya seperti termuat saja. 
Berdasarkan narasi pikiran diatas, penulis berpendapat bahwa, merangkai makna dalam kalimat yang runtut akan menghasilkan kerangka pikir yang unik untuk dikomunikasikan. Harus diakui bahwa, orang yang berpikir kuantitatif dan linear akan selalu membayangkan bahwa segala hal atau fenomenon harus selalu terlihat atau tangible. Sebaliknya orang yang berpikir dan bergumul dengan hal yang sifatnya kualitatif dan behavioral, akan selalu menemukan keunikan-keunikan yang multi-makna dihadapannya. Maka, di era konvergensi saat ini manusia dituntut untuk berpikir nonlinear. Bagi manusia yang tergolong tipe ini, sifat fenomena adalah multi-tafsir dan intangible. Alasannya adalah karena semua yang sifatnya kuantitatif awal-mulanya adalah kualitatif yakni berasal dari logika apriori deduksi Plato.

Dalam introduksi science dikenal adanya kategori-kategori ilmu pengetahuan yang dibagi dalam dua kelompok. Kelompok pertama disebut dengan istilah kompetensi fundamental dasar (Basic Fundamental Competence), dan kompetensi yang selalu mengikuti perkembangan (Trend Competence). Basic fundamental competence adalah semua jenis pengetahuan yang sifatnya mendasar dan menjadi akar atau landasan dari pada potensi Trend comptence.

Pengetahuan filsafat dan jenis humaniora lain yang sudah penulis narasikan panjang lebar diatas, merupakan kompetensi fundamental. Sebaliknya, ilmu-ilmu turunan misalnya: teknik, arsitektur, ilmu komputer, ilmu pertukangan, ilmu biologi-molekuler serta ilmu kehutanan dan pertanian juga ilmu rekayasa lainnya, adalah jenis-jenis ilmu yang senantiasa mengikuti trend atau perkembangan. Dengan kata lain, ilmu-ilmu kompetensi fundamental dasar secara umum tak berwujud, namun menjadi dasar abstraksi kognisi manusia. Sebaliknya, ilmu-ilmu turunan yang sifatnya derivatif selalu berubah mengikuti perkembangan dan terus merubah dunia sesuai perkembangan ilmu dan teknologi itu sendiri. Satu hal yang pasti adalah bahwa, yang tetap adalah perubahan itu sendiri. Yang berubah adalah pikiran manusia untuk men-dinamisasi hidup dan kehidupan.

Dengan materi dan bahan yang sama akan selalu unik dipersepsi oleh orang yang berbeda. Makna yang merambat umumnya diproses oleh logika yang teruji dan terlatih. Sebaliknya, orang yang berpikir pragmatis akan selalu berupaya mengambil makna yang sifatnya pragmatis dan extraktif. Hal ini merupakan gejala umum yang sudah merambah kehidupan manusia modern.

Mengalihkan sikap manusia konsumtif yang pragmatis untuk berperilaku manusiawi adalah suatu keniscayaan yang sepertinya sangat rumit. Itu sebabnya, rumit sekali untuk kita mengaplikasikan ilmu-ilmu yang sifatnya behavioral demi merubah perilaku orang lain yang sudah terbentuk sebelumnya seperti mahasiswa misalnya. Oleh karena itu, membudayakan komunikasi yang elegan menjadi kunci peningkatan budaya manusia sebagai ungkapan diri yang sangat autentik.

Bergumul dengan komunikasi tidaklah cukup hanya memandangnya secara 'ekstraktif dan dekoratif'. Sangat tidak cukup atau belum cukup, jika komunikasi diarahkan hanya untuk 'menghibur'. Meskipun menghibur adalah bagian dari tugas komunikasi. Komunikasi dalam rohnya tidak dimaksudkan hanya untuk 'beretorika', meski retorika adalah seni berkomunikasi. Aristoteles bahkan pernah mengatakan, retorika adalah wujud dan bentuk komunikasi untuk 'memanipulasi' khalayak atau massa yang menjadi komunikan atau audiensnya. Sejumlah pakar lainnya justru berpendapat bahwa retorika adalah suatu seni menyampaikan gagasan kepada konstituen yang menukung seorang tokoh untuk ditampilkan dalam pentas politik.

Dalam konteks ini, kita sebetulnya bergumul dengan diri kita sendiri untuk terus merubah dunia menjadi lebih baik dan menyejahterakan hidup kita. Diujung perjuangan hidup manusia adalah kebahagiaan. Makna hidup terletak pada bagaimana menyikapi hidup dengan bijaksana. Logika komunikasi akan senantiasa bergumul dengan suara hati yang berbisik pada tiap-tiap insan manusia. komunikasi yang diinternalisasi dalam rangka menyampaikan pesan bermakna merupakan inspirasi bagi kita semua. 


\section{Humaniora dan Manusia}

Di abad pertengahan (reneissance), tujuan pendidikan humaniora adalah untuk meningkatkan intelektualitas dan membentuk perilaku manusia berbudi pekerti luhur. Ilmu-ilmu pengetahuan dianggap bertujuan membuat dan membentuk manusia untuk lebih manusiawi. Manusia didorong untuk lebih berbudaya dalam memelihara hidup dan kehidupan. Bidang-bidang ilmu yang dipelihara pada masa ini adalah, Teologi, Filsafat, Hukum, Sejarah, Filologi, Bahasa, Sastra, Kesenian dan Psikologi. Bidang-bidang tersebut diatas muncul ke permukaan secara eksklusif, mendominasi seluruh aspek kehidupan manusia. Pada era ini pula manusia mampu meng-ekspresikan diri sebagai makluk yang sangat mulia oleh karena, kebebasan untuk melihat manusia secara utuh dan menyeluruh. Jika sebelumnya semua bentuk komunikasi selalu dikondisikan menghadap keatas untuk berbicara dengan Tuhan (Theo-Sentris), maka diera reneissance, manusia dibebaskan untuk berkomunikasi secara horisontal bersama temannya sebagai sesama manusia (Antropo-Centris).

Aspek-aspek kehidupan manusia yang mencakup ekonomi, budaya, perdagangan, hukum, sosial dan politik, keamanan serta ilmu pengetahuan dan teknologi, semuanya diperuntukkan bagi kebaikan manusia sebagai faktor tunggal yang menentukkan kehidupannnya. Pertanyaannya adalah bentuk kehidupan yang bagaimana dan seperti apa yang hendak digumuli dan dikejar manusia? jawabnya kemungkinan hampir sama yakni ingin sukses dalam hidup dan bahagia. Setiap manusia pasti memiliki tujuan hidup. Oleh karena itu, memperjuangkan hidup dan kehidupan manusia merupakan realisasi perjuangan manusia untuk memuliakan dirinya. Dalam kemuliaan inilah, seluruh perhatian manusia diarahkan untuk mencapai sukses dan bahagia. Tidak ada gunanya jika seorang manusia memiliki segalanya, namun jiwanya hampa dan gagal menciptakan kebahagiaan. Kehampaan jiwa adalah bentuk nyata dari kehidupan yang gagal.

Manusia dikatakan sukses jika memenuhi dua unsur yang disebutkan diatas yakni, sukses dan bahagia. Sukses adalah abstraksi kehidupan yang sifatnya relatif. Sebaliknya, bahagia adalah wujud nyata kehidupan yang sukses. Sukses belum tentu bahagia. Namun, bahagia kemungkinan besar sukses. Jiwa yang damai adalah fundamen kebahagiaan. Seandainya seseorang ditanya apakah si kaya yang sukses secara ekonomi merasa bahagia? Jawabnya belum tentu. Kemungkinan juga bisa hampa jiwanya. Jiwa yang hampa berarti wujud ketidakbahagiaan dirinya sendiri sebagai manusia. Sebaliknya, seorang ibu rumah tangga biasa yang sukses membina dan membesarkan putra-putrinya, kemungkinan besar jauh lebih bahagia. Semua yang terlihat tidak terungkap bukan merupakan aktualisasi dari eksistensi manusia. Wujud manusia yang terlihat bisa menipu dan memanipulasi situasi hanya untuk menciptakan citra yang menipu bagi sesamanya. Tiap-tiap manusia harus berkontemplasi untuk merefleksikan dirinya dalam situasi yang nyaman dan bahagia.

\section{Humaniora dan Komunikasi}

Tujuan humaniora adalah untuk menaikkan derajat hidup manusia. Menaikkan derajad hidup dari taraf yang rendah ke taraf derajad yang lebih tinggi. Dalam konteks ini komunikasi adalah sarana untuk menaikkan derajad hidup manusia dari level yang rendah ke taraf yang lebih tinggi. Dalam bahasa filsafat, memanusiakan manusia untuk menjadi manusia yang utuh. Utuh dalam wujud dan jiwanya. Semua bentuk komunikasi manusia haruslah bertujuan meningkatkan taraf hidupnya. Komunikasi juga merupakan ungkapan diri manusia untuk memajukan narasi. Narasi yang hebat adalah wujud komunikasi yang hebat pula, dan proses inilah yang disebut proses humanisasi.

Proses peningkatan derajad hidup manusia melalui komunikasi yang bermartabat khas manusia adalah proses humanisasi. Semua bentuk perjuangan dan aktivitas komunikasi harus diarahkan untuk memanusiakan manusia dalam proses humanisasi. Sebaliknya, membudayakan komunikasi yang tak berbudi, merupakan bentuk pengingkaran untuk menegasi kemunusiaan. Aktivitas pengingkaran ini adalah proses merendahkan martabat manusia dan kemanusiaan yang 
disebut dehumanisasi. Dehumanisasi pengikisan existensi manusia sebagai makluk ciptaan Tuhan yang paling mulia dimuka bumi.

\section{PENUTUP}

Menulis merupakan tindakan psikomotor yang diperintah oleh kognisi dan ikut dirasakan oleh aspek afeksi manusia. kognisi merupakan elemen utama dalam diri manusia karena berkaitan langsung dengan eksistensi manusia. manusia yang tidak berpikir berarti hadir secara ragawi, namun tidak hadir secara kualitatif. Itu sebabnya tingkatan berpikir menjadi fokus utama Benyamin Bloom untuk mengolah pikir secara berjenjang meningkat sesuai tatanan taxonomy. Berpikir selalu disamakan dan dianalogikan dengan kehadiran. Dan kehadiran adalah penampakan eksistensi manusia yang utuh. Hadir secara kualitatif tentulah sangat berbeda dengan hadir secara kuantitatif. Tiap tiap manusia diharapkan hadir secara kualitatif. Melatih diri untuk menulis berarti melakukan proses transformasi kognisi untuk merubah bentuk-bentuk dari realitas. Realitas adalah fenomena yang sifatnya konstan tak berubah namun pikiran manusia mampu mengekslorasinya berdasarkan perkembangan ilmu pengetahuan dan teknologi. Merubah bentuk realitas sangat beragam dan bervariasi. Ia sangat tergantung kepada manusia sebagai subjek pengubah. Menulis merupakan proses transformasi pikiran yang disedimentasikan dalam bentuk tulisan. Menulis juga berarti proses merubah bentuk dari realitas sesuai dengan daya kreasi yang diciptakan dan mutlak perintah pikiran manusia.

Halus atau kasarnya perubahan sangat tergantung kepada proses kognisi manusia yang memilikinya. Manusia yang memiliki kebudayaan dan peradaban tinggi adalah mereka yang telah menguasai ilmu pengetahuan dan teknologi dengan baik. Oleh karena itu transformasi perubahan realitas sangat tergantung sepenuhnya kepada penguasaan ilmu pengetahuan dan teknologi. Di pihak lain, proses merubah cara berpikir manusia dari taraf rendah ke taraf berpikir yang lebih tinggi, merupakan proses humanisasi. Sebaliknya pembodohan dan kebodohan adalah proses dehumanisasi. Mengangkat manusia dari taraf derajad rendah ke taraf derajad yang lebih tinggi adalah peradaban manusia modern yang telah maju dalam cara berpikir. Cara meletakkan pendidikan sebagai fundamen perubahan manusia merupakan kunci untuk men-transformasikan kognisi manusia sebagai esensi kehidupan itu sendiri. Sebaliknya komunikasi adalah proses transformasi pikiran untuk disedimentasikan baik secara lisan maupun tulisan, secara verbal dan non-verbal. Berkomunikasi dan mengomunikasikan ide berarti proses merubah bentuk pikiran dari pengirim kepada penerima ide melalui proses encoding dan mengalami rekonstruksi baru pada tahap decoding untuk melahirkan suatu dialog khas manusiawi. Komunikasi juga berarti proses humanisasi yakni mengangkat manusia lain dari taraf derajad yang rendah ke taraf derajad yang lebih tinggi. Ekspetasi dalam berkomunisasi adalah menciptakan harmoni kehidupan.

\section{DAFTAR PUSTAKA}

Brubacher, J. S. (1950). Modern philosophies of education. New York, McGraw-Hill.

Chaffee, J. (1998). The thinker's way: 8 steps to a richer life. Boston, New York: Little Brown.

Phenix, P. H. (1964). Realms of meaning: A Philosophy of the curriculum for general education. New York: McGraw-Hill. 